\title{
Pengembangan Motif Batik dan Diversifikasi Produk Kain Batik Anatomi
}

\author{
Suratman | Suranto | Elisa Herawati* \\ Program Studi Biologi, Fakultas Matematika dan Ilmu Pengetahuan Alam, Universitas Sebelas Maret \\ Jl. Ir. Sutami 36A, Surakarta 57126
}

\begin{abstract}
Abstrak
Batik Anatomi adalah kelompok wirausaha baru yang didirikan oleh alumni Program Studi Biologi FMIPA UNS. Produk Batik Anatomi ini pada mulanya merupakan hasil PKMK (Program Kreativitas Mahasiswa Kewirausahaan) tahun 2009-2010 dari 3 mahasiswa Program Studi Biologi FMIPA UNS yaitu M. Jafron Syah, Annisa Febti Suharsi dan Amirul Mukminin. Sampai saat ini kelompok usaha Batik Anatomi masih terus berjalan walaupun menghadapai berbagai macam permasalahan. Tujuan kegiatan ini adalah untuk memberikan solusi bagi permasalahan mitra yaitu: (i) memperbaiki proses produksi berupa penambahan alat stempel cap batik, (ii) memberikan pelatihan diversifikasi produk berbahan kain batik anatomi, (iii) memberikan penguatan usaha dengan pelatihan pengemasan produk, dan (iv) memberikan pelatihan pemasaran produk. Target kegiatan adalah perbaikan proses produksi melalui penambahan alat stempel cap batik, pelatihan diversifikasi produk berbahan kain batik anatomi, pelatihan pengemasan produk, dan pelatihan pemasaran produk. Metode yang akan digunakan guna mencapai tujuan adalah sebagai berikut: (i) merancang alat stempel cap batik oleh tim pengusul bersama mitra serta menguji coba dan menerapkan alat, (ii) pelatihan dan praktek diversifikasi produk berbahan kain batik anatomi sehingga produknya menjadi lebih beragam, (iii) pelatihan dilanjutkan praktek pengemasan produk dan pembuatan desain kemasan produk yang baik bersama dengan mitra sehingga produk menjadi lebih menarik dan memiliki nilai jual lebih tinggi, (iv) pelatihan pemasaran produk dengan berbagai alternatif metode pemasaran.
\end{abstract}

Kata Kunci: Batik Anatomi, perbaikan produksi, diversifikasi produk, pengemasan, pemasaran

\section{Pendahuluan}

Meningkatkan kesejahteraan masyarakat dapat dicapai salah satunya dengan berwirausaha. Walaupun tidak mudah, menjadi wirausahawan dapat dimulai dari hal-hal yang kecil. Yang menjadi prioritas bagi wirausahawan baru adalah bagaimana mereka dapat menjalankan usahanya, walaupun dalam kondisi terbatas. Bahkan tidak jarang wirausahawan baru harus tertatih-tatih karena tidak memiliki kemampuan managerial yang baik (Rahmawati, 2014). Secara praktis, berwirausaha ada yang menjadikannya sebagai sampingan, tetapi tidak sedikit yang jsutru menjadikannya sebagai sumber kehidupan pokok. Sayangnya, aktivitas berwirausaha bagi pemula tidak lah semudah yang dibayangkan. Banyak kendala yang dihadapi. Namun demikian, menjadi wirausaha pemula perlu diapresiasi sebab sudah menunjukkan keberaniannya untuk menjalani hidup yang penuh tantangan. Dalam berwirausaha banyak produk atau jasa yang bisa dikelola dan dikembangkan salah satunya adalah batik. Batik merupakan salah satu warisan budaya Indonesia yang perlu dilestarikan. UNESCO telah menetapkan batik sebagai warisan kemanusiaan untuk budaya lesan dan non bendawi (Masterpieces of the Oral and Intangible Heritage of Humanity) sejak tanggal 2 Oktober 2009 (Salma, 2013). Di samping itu batik juga memiliki potensi ekonomi yang cukup besar.

\footnotetext{
* Penulis Korespondensi. Email: elisahera@staff.uns.ac.id
} 
Perdagangan produk pakaian jadi di dunia yang mencapai US\$ 442 miliar, menjadi peluang besar bagi industri batik nasional untuk meningkatkan pangsa pasarnya, mengingat batik sebagai salah satu bahan baku produk pakaian jadi. Industri batik nasional memiliki daya saing komparatif dan kompetitif di atas rata-rata dunia. Indonesia menjadi market leader yang menguasai pasar batik dunia. Berdasarkan data Kementerian Perindustrian, pelaku usaha batik di Indonesia didominasi oleh industri kecil dan menengah (IKM) yang tersebar di 101 sentra. Jumlah tenaga kerja yang terserap di sentra IKM batik mencapai 15.000 orang. Nilai ekspor kain batik dan produk batik pada tahun 2016 mencapai US\$149,9 juta dengan pasar utama Jepang, Amerika Serikat, dan Eropa. Data tersebut menunjukkan bahwa industri batik memiliki peran penting bagi penggerak perekonomian nasional melalui penumbuhan wirausaha, penyedia lapangan kerja, dan penyumbang devisa negara (Nurainun et al., 2008; Kementerian Perindustrian RI, 2017).

Motif batik sangat beragam dan terus berkembang. Motif klasik sebagai motif yang sudah ada sejak jaman kerajaan masih terus dilestarikan sampai sekarang terutama di 2 Surakarta dan Yogyakarta, mengingat kedua kota ini mempunyai keraton yang menggunakan kain panjang sebagai busana adat utamanya. Motif klasik mempunyai penggemar dan peminat pada kalangan tertentu, terutama generasi tua. Bagi generasi muda, motif klasik kurang disukai karena identik dengan tua dan kuno. Anak muda juga masih menganggap berpakaian batik terlalu resmi, sehingga hanya digunakan pada acara tertentu, bukan untuk busana harian. Untuk itulah diperlukan inovasi motif agar bisa diterima pada berbagai kalangan, terutama generasi muda karena di tangan merekalah masa depan batik dipertaruhkan. Salah satu alternatif motif batik yang inovatif dan kekinian serta dapat diterima oleh generasi muda adalah motif yang bertemakan keanekaragaman alam dan makhluk hidup.

Batik Anatomi adalah kelompok wirausaha baru yang didirikan oleh alumni Program Studi Biologi FMIPA UNS. Produk Batik Anatomi ini pada mulanya merupakan hasil PKMK (Program Kreativitas Mahasiswa Kewirausahaan) tahun 2009-2010 dari 3 mahasiswa Program Studi Biologi FMIPA UNS yaitu M. Jafron Syah, Annisa Febti Suharsi dan Amirul Mukminin. Batik Anatomi ini sangat unik karena motifnya kebanyakan terinspirasi dari bentuk morfologi maupun anatomi jaringan dari berbagai organ makhluk hidup. Motif Batik Anatomi boleh dibilang berbeda dengan motif batik kebanyakan yang beredar di masyarakat. Bermula dari kegiatan PKMK maka Batik Anatomi ini kemudian dikembangkan sebagai salah satu bidang wirausaha. Setelah dua tahun berturut-turut (2009 dan 2010) mendapat dana hibah PKMK maka mulai didesain beberapa motif. Sampai tahun 2018, sudah ada 9 motif yang telah diciptakan dan dikembangkan oleh Batik Anatomi (Gambar 1).

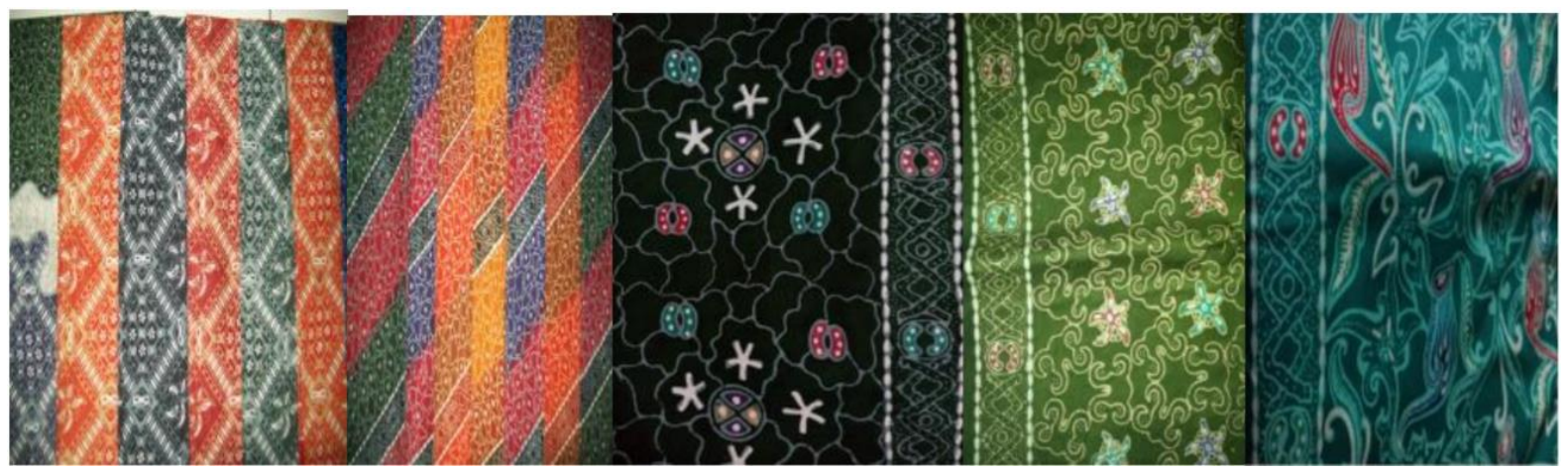

Gambar 1. Beberapa motif Batik Anatomi yang terinspirasi dari anatomi organ berbagai makhluk hidup

Permasalahan di bidang produksi pada kelompok usaha baru ini terutama berkaitan dengan terbatasnya produksi yang diakibatkan oleh terbatasnya pengadaan alat produksi batik (Gambar 2). Alat stempel cap batik ini lumayan mahal harganya. Selama ini alat 3 stempel cap batik hanya tersedia untuk beberapa motif saja (dFari 9 motif hanya tersedia 6 alat stempel cap batik) dan produksinya pun masih 
melibatkan pihak ketiga, yaitu masih memesan kepada salah satu produsen di Sentra Batik Laweyan. Keterbatasan modal masih menjadi kendala bagi wirausahawan ini untuk meningkatkan produksinya.

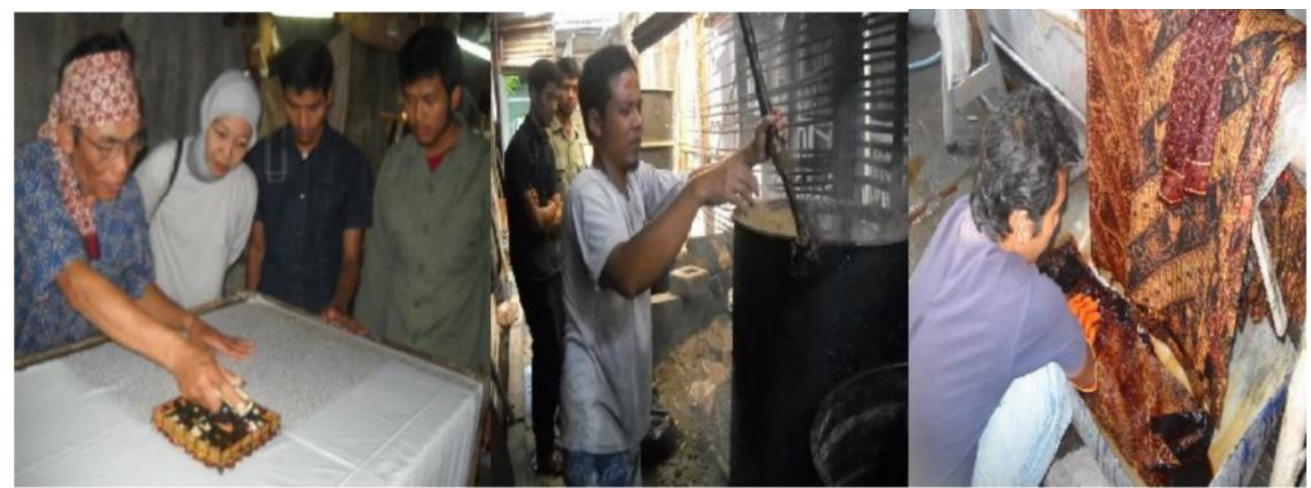

Gambar 2. Proses produksi pembuatan batik dengan menggunakan alat stempel batik yang masih terbatas jumlahnya sehingga volume produksinya tidak maksimal.

Produk yang dihasilkan sekarang pun tidak terlalu beragam dan cenderung monoton karena hanya berupa kain atau baju/pakaian jadi. Mitra usaha telah memiliki tempat usaha yang sederhana, di salah satu ruangan rumah mereka, dimana ruang tamu rumah dibuat menjadi etalase penjualan produknya. Penataan display produk masih dilakukan seadanya. Demikian juga produk yang dijual masih dikemas secara sangat sederhana dan kurang menarik yaitu hanya dibungkus dengan plastik polos (Gambar 3). Pemasaran produk Batik Anatomi selama ini masih dilakukan secara sederhana yaitu dilakukan melalui pameran- pameran sederhana yang tidak dipungut biaya keikutsertaan dan melalui penjualan langsung. Demikian juga promosi produk juga baru dilakukan secara sederhana dari mulut ke mulut atau melalui media sosial sederhana seperti Facebook dan WhatsApp (WA).

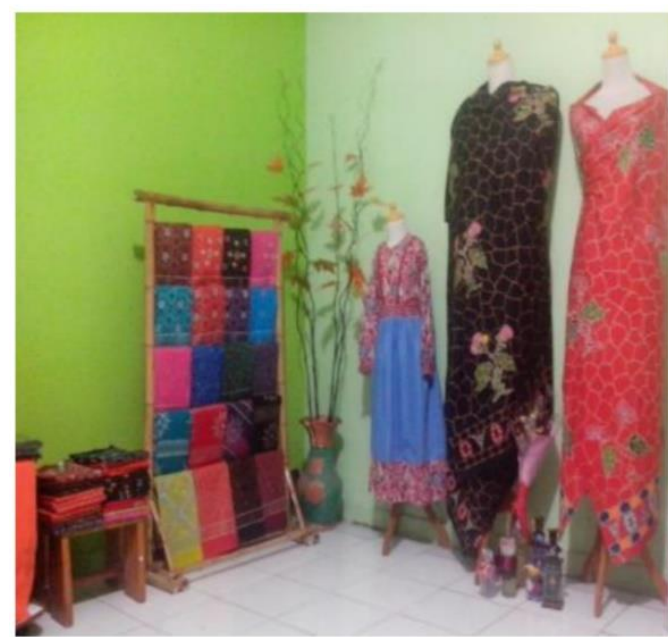

A

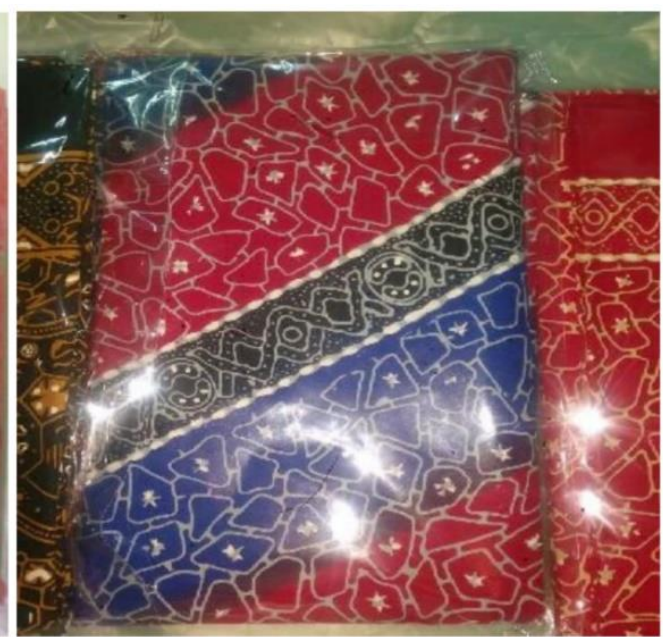

B

Gambar 3. A. Produk yang dijual kebanyakan berupa kain atau baju batik. Etalase penjualan produk pun masih sederhana dengan memanfaatkan ruang tamu; B. Pengemasan produk yang masih sederhana dengan menggunakan plastik polos

Berdasarkan hasil pengamatan, diskusi dan wawancara, bahwa mitra Kelompok Usaha Batik Anatomi belum dikelola secara baik dan benar sehingga mitra usaha menghadapi beberapa permasalahan, yaitu : a). Keterbatasan produksi Permasalahan di bidang produksi berkaitan dengan terbatasnya produksi yang diakibatkan oleh terbatasnya pengadaan alat produksi batik. Selama ini alat stempel cap batik hanya tersedia beberapa motif saja (dari 9 motif hanya tersedia 4 alat stempel cap batik) dan produksinya pun 
masih melibatkan pihak ketiga, yaitu masih memesan kepada salah satu produsen di Sentra Batik Laweyan. Selama ini strategi produksi yang dijalankan baru secara insidental, yaitu jika ada pesanan baru memproduksi. Hal ini dari sisi modal dan pembiayaan memang sekilas terlihat lebih aman, tetapi di sisi yang lain menyebabkan stok produk tidak terlalu banyak. Jika ada pesanan mendadak dan segera dalam jumlah besar masih harus menunggu lama. Masa menunggu sekitar 2 minggu oleh konsumen dianggap terlalu lama, b). Diversifikasi Produk Selain itu diversifikasi produk perlu ditingkatkan karena produk yang ada sekarang terlalu monoton hanya berupa kain atau baju/pakaian jadi. Produk yang tidak unik dan kreatif biasanya akan segera ditinggalkan oleh konsumen, c).Pengemasan produk Selama ini produk Batik Anatomi masih dikemas secara sangat sederhana dan kurang menarik yaitu hanya dibungkus dengan plastik polos sehingga dapat mengurangi harga jual produk. Mitra kurang memahami tentang cara pengemasan yang baik dan informatif bagi konsumen, d). Pemasaran Produk Pemasaran produk Batik Anatomi masih dilakukan secara sederhana yaitu dilakukan melalui pameran-pameran dan melalui penjualan langsung. Demikian juga promosi produk juga baru dilakukan secara sederhana dari mulut ke mulut atau melalui media sosial sederhana seperti Facebook dan WhatsApp (WA).

\section{Metode Pelaksanaan}

\section{Peningkatan proses produksi melalui pembuatan alat stempel cap batik}

Prosedur pembuatan alat stempel cap batik dilakukan melalui beberapa tahapan, yaitu: (i) desain alat, (ii) pabrikasi alat, (iii) uji coba alat, dan (iv) penerapan alat. Desain alat stempel cap batik sudah didiskusikan bersama antara Tim Pengabdi dan mitra sehingga diperoleh desain alat sesuai dengan gambaran ipteks. Berdasarkan desain ini selanjutnya akan dilakukan diskusi lebih lanjut sebelum tahap pabrikasi. Bahan baku untuk keperluan uji coba alat akan disediakan oleh Mitra. Adapun detail alat stempel cap batik yang akan dbuat adalah sebagai berikut : Dimensi alat : 200 x 200 x $50 \mathrm{~mm}$; Berat : 1.000 gram; Bahan : plat tembaga.

Selain itu, untuk melindungi Hak Kekayaan Intelektual milik mitra maka direncanakan akan mendaftarkan motif batik milik mitra ke Direktorat Jenderal Kekayaan Intelektual Kementerian Hukum dan Hak Asasi Manusia.

\section{Pelatihan Diversifikasi Produk}

Untuk meningkatkan diversifikasi produk maka produk tidak hanya berupa kain dan baju batik, tetapi juga produk-produk yang lain seperti tas, sandal, dompet, bando, tempat pensil, gantungan kunci, tempat tissue, dan lain lain. Oleh karena itu perlu dilakukan pelatihan pembuatan beberapa produk yang berbahan dasar kain batik anatomi tersebut. Tim Pengabdi akan memberikan contoh variasi produk olahan kepada mitra dan dilanjutkan dengan praktek pembuatan diversifikasi produk bersama dengan mitra Pelatihan akan diberikan dalam 2 x tatap muka dengan alokasi waktu 3-4 jam untuk setiap tatap muka.

\section{Penguatan usaha melalui pelatihan pengemasan produk}

Guna mendukung pemasaran produk maka akan dilakukan pelatihan desain kemasan. Bentuk pelatihan berupa diskusi bersama dengan mitra dilanjutkan dengan praktek pengemasan produk dan pembuatan desain kemasan produk yang baik bersama dengan mitra sehingga produk menjadi lebih menarik dan memiliki nilai jual lebih tinggi. Dalam pelatihan juga akan diberikan pemahaman tentang cara membuat label kemasan yang baik 10 dan informatif. Pelatihan akan diberikan dalam $2 \times$ tatap muka dengan alokasi waktu 3-4 jam untuk setiap tatap muka.

\section{Pelatihan pemasaran produk}

Pelatihan ini dilakukan dengan memberikan pemahaman dan pengetahuan kepada mitra tentang berbagai macam alternatif cara pemasaran produk berikut dengan langkahlangkah pemasarannya. Tim 
Pengabdi memfokuskan pada pemasaran melalui media online yang lebih mudah menjangkau konsumen seperti website, blog, vlog atau menggunakan teknologi digital e-commerce melalui tokotoko penjualan online seperti Shopee, Buka Lapak, dan sebagainya. Direncanakan pelatihan dilakukan dalam 2 x tatap muka dengan alokasi waktu 3-4 jam untuk setiap tatap muka.

\section{Metode Pendekatan}

Untuk menggali permasalahan yang dihadapi oleh mitra maka metode awal yang akan digunakan adalah berupa diskusi dua arah atau Focus Group Discussion (FGD). Metode FGD merupakan interaksi individu-individu yang oleh seorang pemandu diarahkan untuk mendiskusikan pemahaman dan atau pengalamannya tentang suatu program atau kegiatan yang diikuti dan ataudicermatinya (Mardikanto, 2009). Pada program PKM ini, FGD diterapkan untuk memecahkan masalah tentang peran kelembagaan dalam penguatan mitra melalui perbaikan produksi, diversifikasi produk, pengemasan produk dan pemasaran produk. Metode diskusi ini ditujukan agar khalayak sasaran turut berpartisipasi aktif dalam kegiatan ini sehingga dapat mencari solusi yang terbaik dalam usahanya. Peran serta dari mitra nantinya akan membuat mereka lebih mandiri dalam mencari solusi permasalahan usahanya.

Setelah berhasil diidentifikasi permasalahan yang dihadapi oleh mitra maka Tim Pengabdi merumuskan solusi permasalahan dan kemudian ditawarkan kepada mitra. Dalam merealisasikan solusi permasalahan ini kemudian dirancang berbagai tahapan kegiatan. Pelaksanaan kegiatan sebagai solusi untuk permasalahan yang dihadapi oleh mitra antara lain berupa (i) Peningkatan proses produksi melalui pembuatan alat stempel cap batik, (ii) Pelatihan Diversifikasi Produk, (iii) Penguatan usaha melalui pelatihan pengemasan produk, dan (iv) Pelatihan pemasaran produk. Kegiatan ini dilaksanakan dengan menggunakan metode Participatory Learning and Action (PLA) atau dahulu dikenal sebagai learning by doing. Participatory Learning and Action (PLA) merupakan metode penyuluhan atau 11 pelatihan yang terdiri dari proses belajar dan diikuti dengan aksi atau kegiatan riil dari peserta kegiatan yang relevan dengan materi yang disampaikan.

\section{Partisipasi Mitra}

Mitra merupakan penyedia bahan baku pelatihan diversifikasi produk, pengemasan produk dan pemasaran produk sekaligus sumber tenaga kerja dalam proses pelatihan. Mitra juga merupakan pengguna yang akan menerapkan alat, dan pengetahuan yang telah diberikan selama proses pelatihan dan pendampingan usaha.

\section{Evaluasi Pelaksanaan dan Keberlanjutan Program}

Evaluasi kegiatan dilakukan oleh Tim Pengabdi PKM terutama ditujukan kepada mitra, meliputi aktivitas selama kegiatan pengabdian dan capaian pada saat kegiatan berakhir. Dalam kegiatan pengabdian kepada masyarakat ini, dilakukan beberapa tahapan evaluasi, yaitu: 1). Evaluasi pendahuluan dilakukan dengan membuat kuesioner sebelum kegiatan berlangsung (pre test) mengenai pengetahuan tentang kinerja produksi, diversifikasi produk, pengemasan produk dan pemasaran produk. 2). Evaluasi selama kegiatan berlangsung yaitu dengan memonitor jalannya kegiatan untuk memastikan target luaran dapat tercapai. 3). Evaluasi setelah kegiatan dilakukan (post test) dengan cara praktek pembuatan diversifikasi produk, pengemasan produk dan pemasaran produk. Tolak ukur keberhasilan kegiatan diketahui dengan cara menilai atau membandingkan nilai pre test dengan post test sebelum dan sesudah kegiatan PKM dilaksanakan. Kriteria penilaian terdiri dari peningkatan pengetahuan dan keterampilan mitra tentang kinerja produksi, diversifikasi produk, pengemasan produk dan pemasaran produk. Indikator keberhasilan yang diharapkan apabila 50\% khalayak sasaran dapat menerapkan transfer teknologi yang diberikan. Dalam rangka memonitoring keberlanjutan program maka setelah kegiatan PKM selesai dilaksanakan, Tim Pengabdi akan tetap memonitoring mitra usaha dengan 
melakukan komunikasi dengan mitra usaha dan memonitoring langsung ke lokasi usaha untuk mengetahui adanya tidaknya kendala dalam penggunaan alat dan pengelolaan manajemen usaha.

\section{Hasil dan Pembahasan}

\section{Peningkatan proses produksi melalui pembuatan alat stempel cap batik}

Untuk membantu peningkatan proses produksi kain batik pada mitra wirausahawan Batik Anatomi maka Tim Pengabdi mendampingi mitra melakukan pembuatan desain dan pemesanan alat stempel cap cetak batik. Desain alat stempel cap batik sudah didiskusikan bersama antara Tim Penbdi dan mitra. Adapun detail alat stempel cap batik yang akan dibuat adalah sebagai berikut : Dimensi alat : $200 \times 200$ x $50 \mathrm{~mm}$ Berat : 1.000 gram Bahan : plat tembaga sehingga diperoleh contoh desain alat seperti yang ditunjukkan pada Gambar 4. Berdasarkan desain ini selanjutnya akan dilakukan pemesanan ke pihak penyedia jasa pembuatan alat cetak batik, kemudian dicetak pada kain seperti pada Gambar 5 .

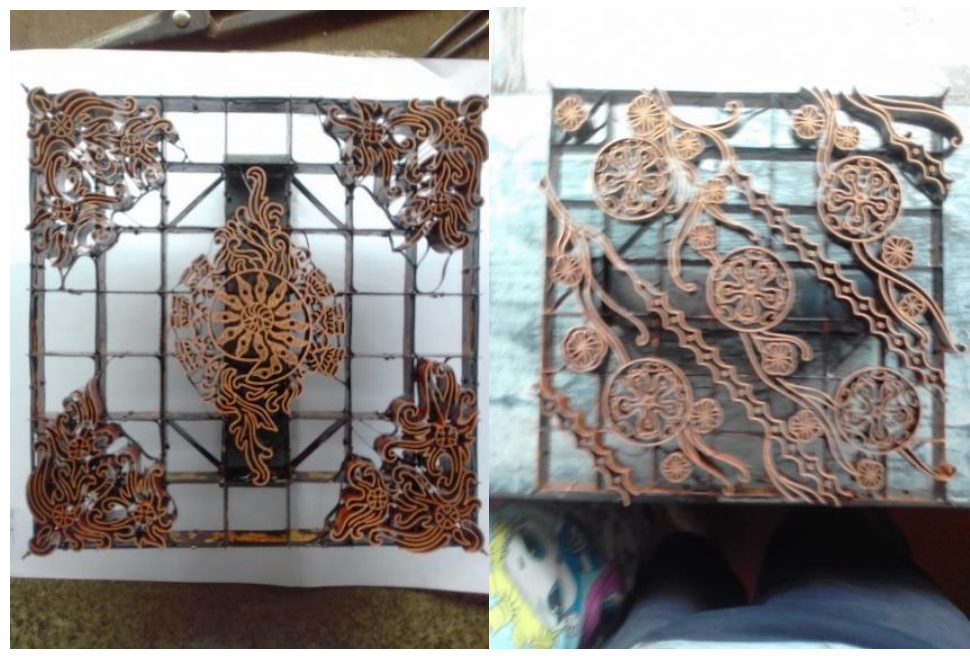

Gambar 4. Alat stempel berbahan perunggu untuk motif batik yang baru, yaitu Motif Foraminifera 1 (kiri) dan Protista 1 (kanan).

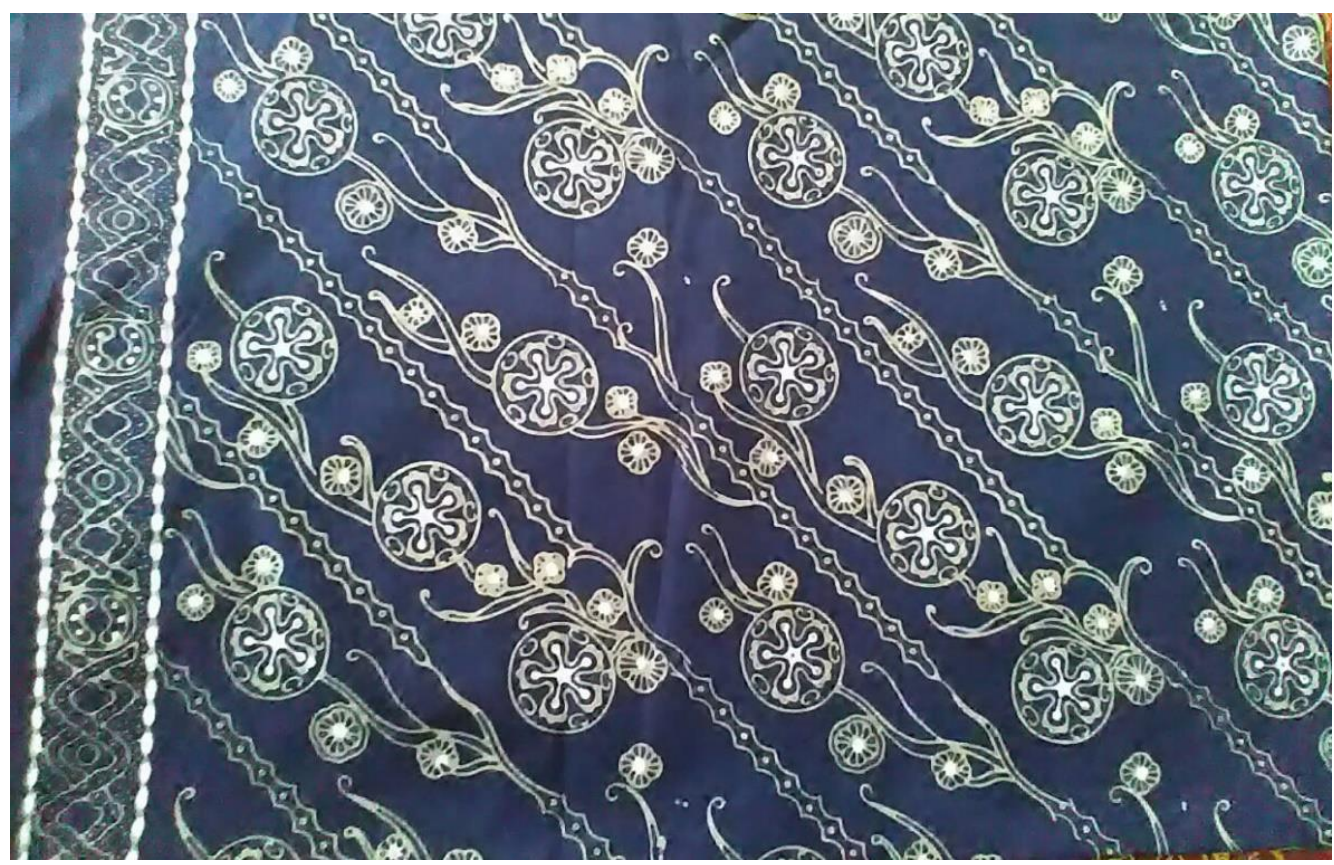

Gambar 5. Kain batik dengan motif Protista 1 yang siap dipasarkan 
Selain itu, untuk melindungi Hak Kekayaan Intelektual milik mitra maka saat ini Tim Pengabdi telah mendaftarkan Hak Cipta untuk 5 motif batik yaitu motif DNA Double Helix, Jamur, Fertilisasi, Anther dan Epidermis ke Direktorat Jenderal Kekayaan Intelektual Kementerian Hukum dan Hak Asasi Manusia melalui Divisi Kekayaan Intelektual Badan Pengelola Usaha (BPU) Universitas Sebelas Maret. 16. Untuk motif baru Protista 1 dan Foraminifera 1 juga telah memiliki Surat Pencatatan Ciptaan tahun 2019.

\section{Pelatihan Diversifikasi Produk}

Untuk meningkatkan diversifikasi produk maka produk tidak hanya berupa kain dan baju batik, tetapi juga produk-produk yang lain seperti tas, dompet dan lain lain. Oleh karena itu dilakukan pelatihan pembuatan beberapa produk yang berbahan dasar kain batik anatomi tersebut (Gambar 7). Tim pengabdi memberikan contoh variasi produk olahan kepada mitra dan dilanjutkan dengan praktek pembuatan diversifikasi produk bersama dengan mitra. Pelatihan diberikan dalam $2 \mathrm{x}$ tatap muka dengan alokasi waktu 3-4 jam untuk setiap tatap muka. Pelatihan ini dilaksanakan di Oemah Batik Anatomi yang berlokasi di Jalan Salak 5 No. 127, Perum Ngringo, Jaten, Karanganyar.
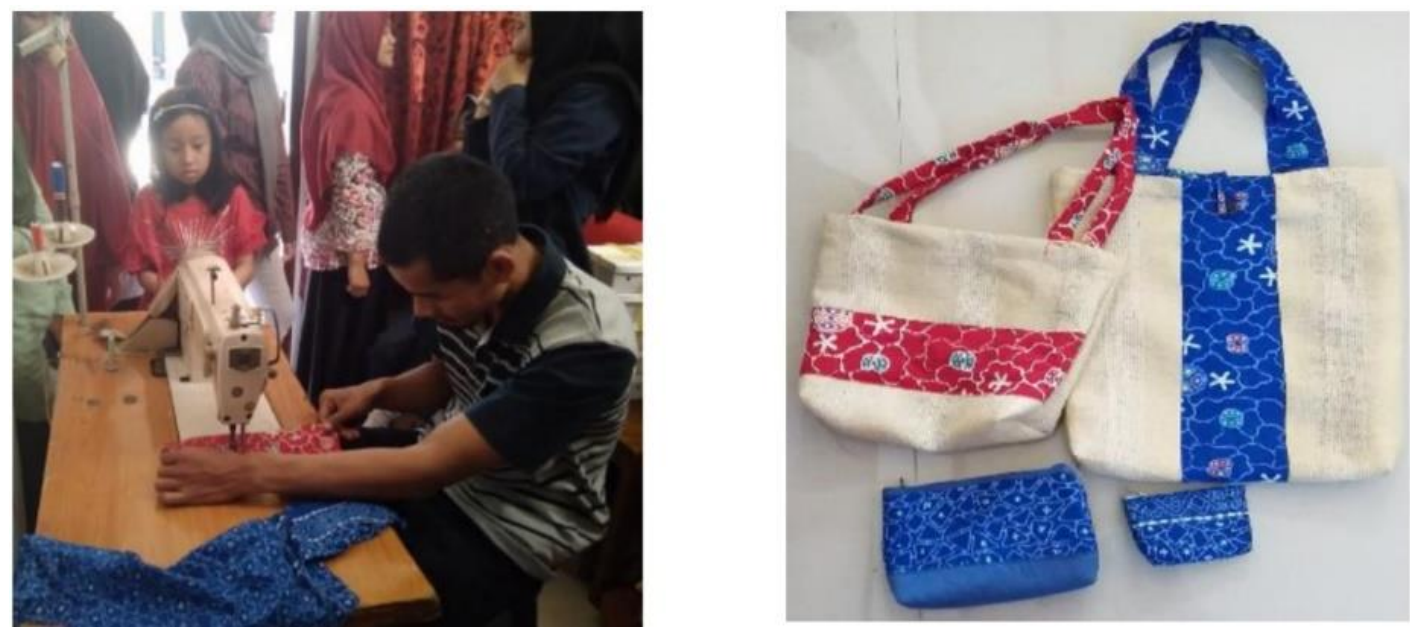

Gambar 7. Pelatihan diversifikasi produk Batik Anatomi (kiri); Contoh diversifikasi produk yang berbahan kain Batik Anatomi (kanan)

\section{Penguatan usaha melalui pelatihan pengemasan produk}

Guna mendukung pemasaran produk maka dilakukan pelatihan desain kemasan. Bentuk pelatihan berupa diskusi bersama dengan mitra dilanjutkan dengan praktek pengemasan produk dan pembuatan desain kemasan produk yang baik bersama dengan mitra sehingga produk menjadi lebih menarik dan memiliki nilai jual lebih tinggi. Dalam pelatihan juga akan diberikan pemahaman tentang cara membuat label kemasan yang baik dan informatif. Pelatihan akan diberikan dalam $2 \times$ tatap muka dengan alokasi waktu 3-4 jam untuk setiap tatap muka. Pelatihan ini dilaksanakan di Oemah Batik Anatomi yang berlokasi di Jalan Salak 5 No. 127, Perum Ngringo, Jaten, Karanganyar.

\section{Pelatihan pemasaran produk}

Pelatihan ini dilakukan dengan memberikan pemahaman dan pengetahuan kepada mitra tentang berbagai macam alternatif cara pemasaran produk berikut dengan langkah-langkah pemasarannya. Tim pengabdi memfokuskan pada pemasaran melalui media online yang lebih mudah menjangkau konsumen seperti website, blog, vlog atau menggunakan teknologi digital e-commerce melalui tokotoko penjualan online seperti Shopee, Buka Lapak, dan sebagainya. Pelatihan dilakukan dalam $2 \mathrm{x}$ tatap muka dengan alokasi waktu 3-4 jam untuk setiap tatap muka. Pelatihan ini dilaksanakan di Oemah Batik Anatomi yang berlokasi di Jalan Salak 5 No. 127, Perum Ngringo, Jaten, Karanganyar. 
Jurnal SEMAR Vol. 8 No. 1, 2019 hal. $14-21$

\section{Kesimpulan}

Tim Pengabdi PKM telah berhasil melaksanakan kegiatan pendampingan mitra wirausahawan Batik Anatomi berupa peningkatan proses produksi melalui pembuatan alat stempel cap batik serta mendaftarkan Hak Cipta untuk 5 motif batik milik mitra dalam rangka untuk melindungi Hak Kekayaan Intelektual milik mitra, pelatihan diversifikasi produk, penguatan usaha melalui pelatihan pengemasan produk dan pelatihan pemasaran produk sehingga diharapkan mitra bisa meningkatkan kinerja produksi, kualitas produk, variasi produk, pengemasan produk dan pemasaran produk..

\section{Referensi}

Mardikanto, T. 2009. Sistem Penyuluhan Pertanian. Surakarta : UNS Press.

Nurainun, Heriyana, dan Rasyimah. 2008. Analisis Industri Batik Di Indonesia. Jurnal Fokus Ekonomi 7 (3) : 124-135

Kementerian Perindustrian RI. 2017. Pewarna Alam Batik Kurangi Impor Sintetik. http://www.kemenperin.go.id/artikel/17678/Pewarna-Alam-Batik-Kurangi-Impor- Sintetik [Diakses 8 Februari 2018]

Rahmawati, O. 2014. Upaya Peningkatan Kesejahteraan Perekonomian Masyarakat Melalui Usaha Keripik Belut di Kelurahan Sidoagung Kecamatan Godean. Skripsi. Yogyakarta : Jurusan Pengembangan Masyarakat Islam, Fakultas Dakwah dan Komunikasi Universitas Islam Negeri Sunan Kalijaga

Salma, I.R. 2013. Corak Etnik Dan Dinamika Batik Pekalongan (Ethnic Pattern and Dynamics Pekalongan Batik). Jurnal Dinamika Kerajinan dan Batik 30 (2) : 87-89. 